\title{
Increased serum serotonin improves parturient calcium homeostasis in dairy cows
}

\author{
Lorenzo E. Hernández-Castellano, ${ }^{*}$ Laura L. Hernandez, $†$ Samantha Weaver, $†$ and Rupert M. Bruckmaier ${ }^{* 1}$ \\ *Veterinary Physiology, Vetsuisse Faculty, University of Bern, CH-3001 Bern, Switzerland \\ †Department of Dairy Science, University of Wisconsin, Madison 53706
}

\begin{abstract}
Hypocalcemia in dairy cows is caused by the sudden increase in calcium demand by the mammary gland for milk production at the onset of lactation. Serotonin (5HT) is a key factor for calcium homeostasis, modulating calcium concentration in blood. Therefore, it is hypothesized that administration of 5-hydroxy-L-tryptophan (5-HTP), a 5-HT precursor, can increase 5-HT concentrations in blood and, in turn, induce an increase in blood calcium concentration. In this study, 20 Holstein dairy cows were randomly assigned to 2 experimental groups. Both groups received a daily i.v. infusion of 1 $\mathrm{L}$ of either $0.9 \% \mathrm{NaCl}$ (C group; $\mathrm{n}=10$ ) or $0.9 \% \mathrm{NaCl}$ containing $1 \mathrm{mg}$ of $5-\mathrm{HTP} / \mathrm{kg}$ of BW (5-HTP group, $\mathrm{n}=10)$. Infusions started $\mathrm{d} 10$ before the estimated parturition and ceased the day of parturition, resulting in at least $4 \mathrm{~d}$ of infusion (8.37 $\pm 0.74 \mathrm{~d}$ of infusion). Until parturition, blood samples were collected every morning before the infusions, after parturition samples were taken daily until d 7 , and a final sample was collected on d 30. Milk yield was recorded during this period. No differences between groups were observed for blood glucose, magnesium, and $\beta$-hydroxybutyrate. Cows receiving the 5-HTP infusion showed an increase in fatty acid concentrations from $\mathrm{d}-3$ to -1 before parturition. Serum 5-HT concentrations were increased at $\mathrm{d}-4$ related to parturition until d 5 postpartum in the 5-HTP group compared with the $\mathrm{C}$ group. In addition, cows from the 5-HTP group had increased 5 -HT concentrations in colostrum, but not in mature milk, on d 7 postpartum. Serum calcium concentrations decreased in both groups around parturition; however, calcium remained higher in the 5-HTP group than in controls, with a significant difference between groups on d $1(1.62 \pm 0.08$ vs. $1.93 \pm 0.09 \mathrm{mmol} / \mathrm{L}$ in control and 5 -HTP groups, respectively) and d $2(1.83 \pm 0.06$ vs. $2.07 \pm 0.07 \mathrm{mmol} / \mathrm{L}$ in control and 5 -HTP groups,
\end{abstract}

Received June 19, 2016.

Accepted October 24, 2016.

${ }^{1}$ Corresponding author: rupert.bruckmaier@vetsuisse.unibe.ch respectively). Additionally, colostrum yield (first milking) was lower in the 5-HTP group compared with the C group, but without consequences on colostrum IgG concentrations. Milk yield did not differ between groups during the rest of the experiment. The study data were consistent with the concept that infusion of 5-HTP to dairy cows increases blood 5-HT concentrations, which in turn is a significant regulatory component in the chain of effectors that affect calcium status around parturition, hence the occurrence of clinical or subclinical hypocalcemia.

Key words: serotonin, hypocalcemia, calcium, 5-hydroxy-L-tryptophan

\section{INTRODUCTION}

Hypocalcemia (HC) is a frequent problem in parturient dairy cows (Oetzel, 1988). According to Reinhardt et al. (2011), in countries with high-yielding cows the incidence of clinical hypocalcemia (calcium concentration $<1.5 \mathrm{mmol} / \mathrm{L}$ ) is estimated to be $5 \%$. Hypocalcemia is caused by the inability to maintain appropriate circulating calcium concentrations in blood as a consequence of the abrupt demand of calcium by the mammary gland during transition from pregnancy to lactation. Hypocalcemia is known to affect many intracellular functions (Martinez et al., 2012) and to increase the risk of numerous production-related diseases in transition cows, compromising not only animal welfare but also performance. Calcium is required for muscle contraction, and therefore inappropriate concentrations affect the function and motility of the rumen, abomasum, intestine, and uterus (Cameron et al., 1998; Kimura et al., 2006; Goff, 2008), with severe consequences on energy metabolism. Prevention of $\mathrm{HC}$ in dairy cows is based either on the administration of calcium (Goff, 2008; Gelfert et al., 2010) or on the prepartum inclusion of diets with a high content of anionic salts, such as chloride or sulfate salts (Charbonneau et al., 2006). These salts reduce the dietary cation-toanion ratio with the aim of decreasing blood $\mathrm{pH}$, which is compensated in part by bones accepting hydrogen ions in exchange for calcium (Lemann et al., 2003). 
However, the dosage of calcium that needs to be administered to prevent $\mathrm{HC}$ differs between cows and depends on factors such as age or previous HC problems. As a limitation, the very low palatability of anionic salts can cause a reduction of feed intake (Moore et al., 2000), which is already low during the last $3 \mathrm{wk}$ before parturition. This reduction in the feed intake increases the risk of various production-related diseases such as mastitis due to impaired immune function (Compton et al., 2007). Therefore, the development of more efficient approaches to avoid HC without the aforementioned negative side-effects is necessary.

Serotonin (5-hydroxytryptamine; 5-HT), a biogenic amine and tryptophan derivative, is synthesized in the central nervous system, regulating physiological processes related to mood or appetite, and in many peripheral tissues, including the mammary gland. Serotonin has been demonstrated to regulate mammary gland metabolism, including the regulation of calcium concentration in blood transferred from bone (Hernandez et al., 2008, 2007, 2012,). In addition, 5-HT has been also suggested to regulate energy balance, mainly through the modulation of glucose and lipid metabolism (Sugimoto et al., 1990; Watanabe et al., 2014; Laporta et al., 2015). Thus, the presence of 5-HT receptors in several immune cells and the ability of these cells to take up 5-HT suggest that 5-HT influences the activity of the innate and adaptive immune system (Ahern, 2011; Baganz and Blakely, 2013). As it has been described by Hernández-Castellano et al. (2014), the immune status can influence the transfer of immune components from blood to colostrum. As a consequence, it can be hypothesized that 5-HT may also affect IgG concentrations in colostrum. Based on the known actions of 5 -HT, we tested the hypothesis that administration of 5-hydroxy-L-tryptophan (5-HTP), a 5-HT precursor, causes elevated serum 5-HT concentrations and, in turn, increases calcium concentrations, thus reducing the incidence of $\mathrm{HC}$ in cows around parturition $( \pm 3 \mathrm{~d}$ relative to parturition).

\section{MATERIALS AND METHODS}

This study was approved by the Cantonal Committee of Animal Experiments (Canton of Fribourg, Switzerland) and all experimental procedures followed the Swiss law of animal protection. Animal health status was monitored (for diarrhea, mastitis, and fever) and animals did not experience any symptoms of illness apart from those expected in this study (those related to $\mathrm{HC}$ such as paresis and fine tremors over the flanks and triceps). At parturition, all cows had an optimal BCS (ranged from 3.0 to 3.5).

\section{Animals and Treatments}

Twenty multiparous Holstein dairy cows from the Agroscope research station (Posieux, Switzerland) were randomly assigned to 2 experimental groups of 10 animals each [control (C) group and 5-HTP group). On the day before the start of infusions, cows were fitted with indwelling intravenous catheters (Abbocath-T; Hospira Deutschland GmbH, Munich, Germany) with a length of $14 \mathrm{~cm}$ and a diameter of 14 gauge in the jugular vein. Both groups received a daily i.v. infusion of $1 \mathrm{~L}$ of either $0.9 \% \mathrm{NaCl}$ (C group) or $0.9 \% \mathrm{NaCl}$ containing $1 \mathrm{mg}$ of $5-\mathrm{HTP} / \mathrm{kg}$ of BW (5-HTP group). According to Laporta et al. (2015), this 5-HTP dosage increased blood 5 -HT concentration in late-lactation cows. Infusions lasted for $1 \mathrm{~h}(0700-0800 \mathrm{~h})$ and were performed from $\mathrm{d}$ -10 before the predicted parturition until parturition. Blood samples were collected every morning before the infusions before calving and daily after parturition until d 7. An additional sample was collected on d 30 postpartum. Milk yield of all individual morning and evening milkings was recorded until d 30 postpartum. During the experimental period cows received hay ad libitum $(\mathrm{DM}$ content $=890 \mathrm{~g} / \mathrm{kg}$ of fresh matter, on $\mathrm{s}$ $\mathrm{DM}$ basis, consisting of $125 \mathrm{~g}$ of $\mathrm{CP} / \mathrm{kg}, 235 \mathrm{~g}$ of crude fiber $/ \mathrm{kg}, 14.6 \mathrm{~g} / \mathrm{kg}$ of calcium, and $5.7 \mathrm{MJ}$ of $\mathrm{NE}_{\mathrm{L}} / \mathrm{kg}$ ) and had free access to water. In addition, cows received concentrate supplementation (consisting of wheat bran, apple pomace, oats, magnesium oxide, molasses, and a vitamin-mineral premix) to meet their energy and nutrient requirements according to the guidelines published by Agroscope (2015). Briefly, cows received and consumed a concentrate $\left(6 \mathrm{MJ}\right.$ of $\mathrm{NE}_{\mathrm{L}} / \mathrm{kg}$ of DM and 5 $\mathrm{g}$ of calcium $/ \mathrm{kg}$ ) before and after parturition $(0.5$ and $2.5 \mathrm{~kg} / \mathrm{d}$ and cow, respectively). In addition, cows were supplemented with a vitamin-mineral premix providing $2.5 \mathrm{~g}$ of calcium/d before parturition and $31.8 \mathrm{~g}$ of calcium/d after parturition.

\section{Sample Collection}

Blood samples were taken from the jugular catheter and placed into tubes for plasma collection, containing 3K-EDTA, as well as tubes for serum collection. Blood was stored on wet ice until centrifugation at 2,500 $\times$ $g$ for 20 min at $4^{\circ} \mathrm{C}$ to obtain either plasma or serum, which was stored at $-80^{\circ} \mathrm{C}$ until analysis. Milk samples were aliquoted and then stored at $-80^{\circ} \mathrm{C}$.

\section{Variables Measured in Plasma and Serum}

Glucose, fatty acid, and BHB plasma concentrations were measured using commercial kits from Randox 
(GL364, FA115, and RB1007, respectively; Randox Laboratories Ltd., Schwyz, Switzerland). Total calcium serum concentrations were determined using a commercial kit from Diatools (DIA00461, Diatools AG, Villmergen, Switzerland). Magnesium serum concentrations were determined using a commercial kit from Randox (MG531, Randox Laboratories Ltd.). Serotonin concentrations in serum were determined using a commercial 5-HT ELISA (IM1749, Beckman Coulter GmbH, Sinsheim, Germany).

\section{Variables Measured in Colostrum and Milk}

Total IgG concentration in colostrum was measured using a commercial ELISA kit specific to bovine IgG (Bethyl Laboratories, Montgomery, TX) with some modifications as described by Lehmann et al. (2015). Similar to blood, 5-HT concentrations in colostrum and milk were determined using a commercial 5-HT ELISA (IM1749, Beckman Coulter GmbH).

\section{Statistical Analysis}

All results are presented as means \pm SEM. Statistical analyses were performed using SAS software (version 9.4, SAS Institute Inc., Cary, NC). The MIXED procedure was used to evaluate changes during the experimental period and differences between treatments around parturition (from $\mathrm{d}-4$ to 7 postpartum) and $\mathrm{d}$ 30 postpartum. The final model included the treatment $(\mathrm{C}$ vs. 5-HTP), the experimental period, and the interaction between both as dependent variables and the animal as a repeated effect. Finally, a Tukey-Kramer test was used to evaluate differences between groups. Values were considered significant when $P<0.05$.

\section{RESULTS}

\section{General Observations}

In the present study, infusions started $10 \mathrm{~d}$ before the expected parturition. Because the day of parturition in the experimental animals ranged from d 279 to 286 of pregnancy, infusions were performed for a range of 4 to $10 \mathrm{~d}$ before parturition. The distribution of day of gestation at parturition did not differ between treatments $(280.5 \pm 0.9$ vs. $280.6 \pm 1.0 \mathrm{~d}$ of pregnancy in $\mathrm{C}$ and 5-HTP groups, respectively). None of the studied variables were affected by the number of 5-HTP infusions per cow before parturition ( 7 to 10 infusions vs. 4 to 6 infusions). Therefore, the first sample before the start of the infusions (B) and from $\mathrm{d}-4$ until the end of the experimental period were evaluated in this study. During our study, none of the cows in the 5-HTP group showed HC symptoms. Conversely, 3 cows from the C group $(30 \%)$ succumbed to clinical $\mathrm{HC}$ after parturition (from d 1-2) and required therapeutic intervention. One individual cow that received 5-HTP only once due to its early calving exhibited clinical HC $1 \mathrm{~d}$ after postpartum with a calcium concentration of $1.12 \mathrm{mmol} / \mathrm{L}$ on d 1 after postpartum (data from this cow was not included in the statistical evaluations).

\section{Blood Constituents}

Before the start of infusions, no differences in 5-HT concentrations were detected between groups (Figure 1A). From d -4 to 4 postpartum, cows from the 5-HTP group had higher 5-HT concentration in the circulation than those from the $\mathrm{C}$ group; however, we did not observe any differences between groups on d 5, 6, 7, and 30 postpartum. During the experimental period, time did not have an effect on 5-HT concentrations in the $\mathrm{C}$ group. Conversely, in the 5 -HTP group, 5 - HT concentration was significantly higher from d -4 to 4 , although 5-HT started to decline at $\mathrm{d} 1$ and was not significantly different from d 5 to the end of the experimental period.

Calcium concentrations were similar in both groups at the beginning of the experiment (Figure 1B). Despite the decreased calcium concentration in both groups from d -2 to parturition, calcium concentrations remained higher in the 5-HTP group compared with the C group postpartum $(P<0.05)$. The most dramatic differences between groups were observed on $\mathrm{d} 1$ when some of the cows from the $\mathrm{C}$ group exhibited calcium concentrations below $1.0 \mathrm{mmol} / \mathrm{L}$ (Figure 1C).

Concentrations of glucose (Figure 2A), BHB (Figure 2B), and magnesium (Figure 2C) did not differ between groups during the whole experimental period. Glucose concentrations increased in both groups around parturition (d $0 ; P<0.05)$. Thereafter, glucose decreased progressively until d 2 postpartum and then remained constant until the end of the experimental period. Beta-hydroxybutyrate increased in both groups from $d$ 1 to 7 after parturition $(P<0.05)$ and decreased again by d $30(P<0.05)$. Serum magnesium concentrations decreased in both groups from d 1 to 3 after parturition $(P<0.05)$ and were then restored to normal concentrations on $\mathrm{d} 30(P<0.05)$.

At the beginning of the experiment (B), fatty acids remained at basal levels in both groups (Figure 2D). Cows from the 5-HTP group had higher fatty acid concentrations than the $\mathrm{C}$ group on $\mathrm{d}-3,-2$, and -1 relative to parturition $(P<0.05)$. We did not detect any differences between groups for the rest of the experimental period. Fatty acid concentration increased from $\mathrm{d}-4$ to either $\mathrm{d}-1$ (5-HTP group) or 0 (C group) 
and remained constant until d 7 postpartum. In both groups, fatty acid concentrations were decreased on $\mathrm{d}$ 30 compared with the first $7 \mathrm{~d}$ postpartum.

\section{Colostrum and Milk Constituents}

Colostrum yield from the first milking after calving was decreased $(P<0.05)$ in the 5 -HTP group $(5.90 \pm$ $0.56 \mathrm{~kg})$ compared with the $\mathrm{C}$ animals $(8.23 \pm 0.56 \mathrm{~kg})$. However, we did not observe differences in milk yield in either group during the following 3 milkings postpartum (Figure 3). Milk yield increased in both groups from parturition to d $30(P<0.05)$; however, during the rest of the experimental period (from d 2-30), no differences in milk yield were observed between groups (data not shown).

As shown in Figure 4, 5-HT concentration in colostrum from 5-HTP cows was increased in colostrum compared with $\mathrm{C}$ cows $(P<0.05)$, although we did not find any differences between milk samples in the 5-HTP and $\mathrm{C}$ groups on $\mathrm{d} 7(P<0.05)$. In both groups, we measured elevated 5-HT concentrations in colostrum (d $0)$ than mature milk $(\mathrm{d} 7)(P<0.05)$. Immunoglobulin $\mathrm{G}$ concentrations in the first colostrum collected post-
A

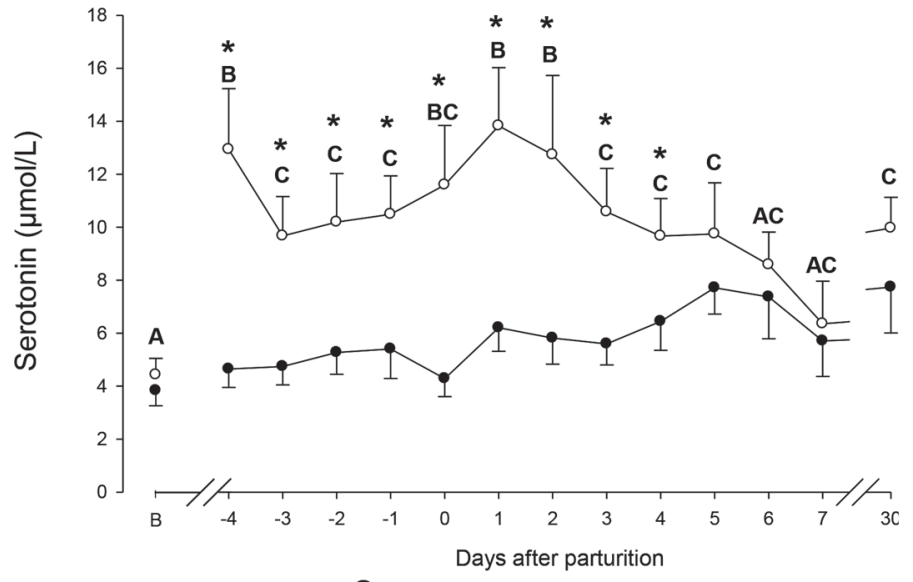

C
B

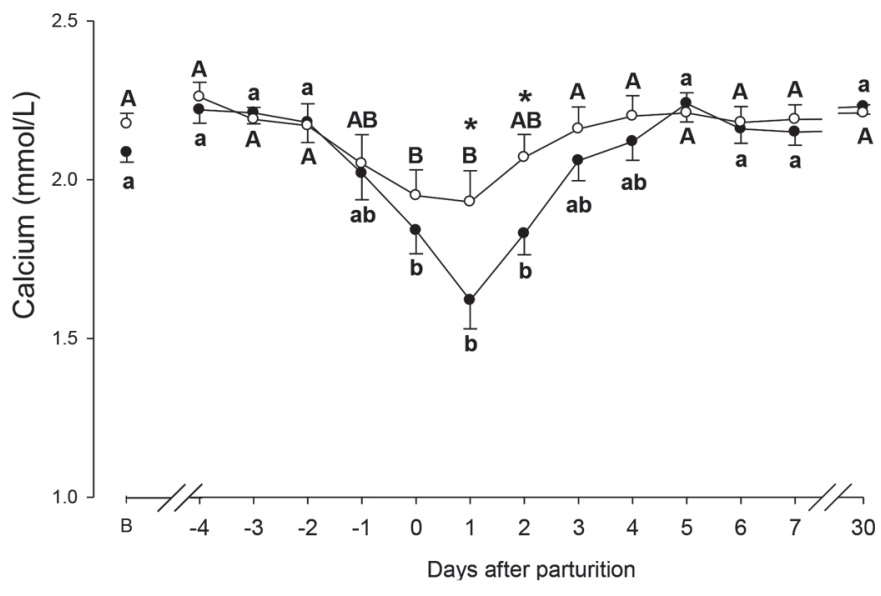

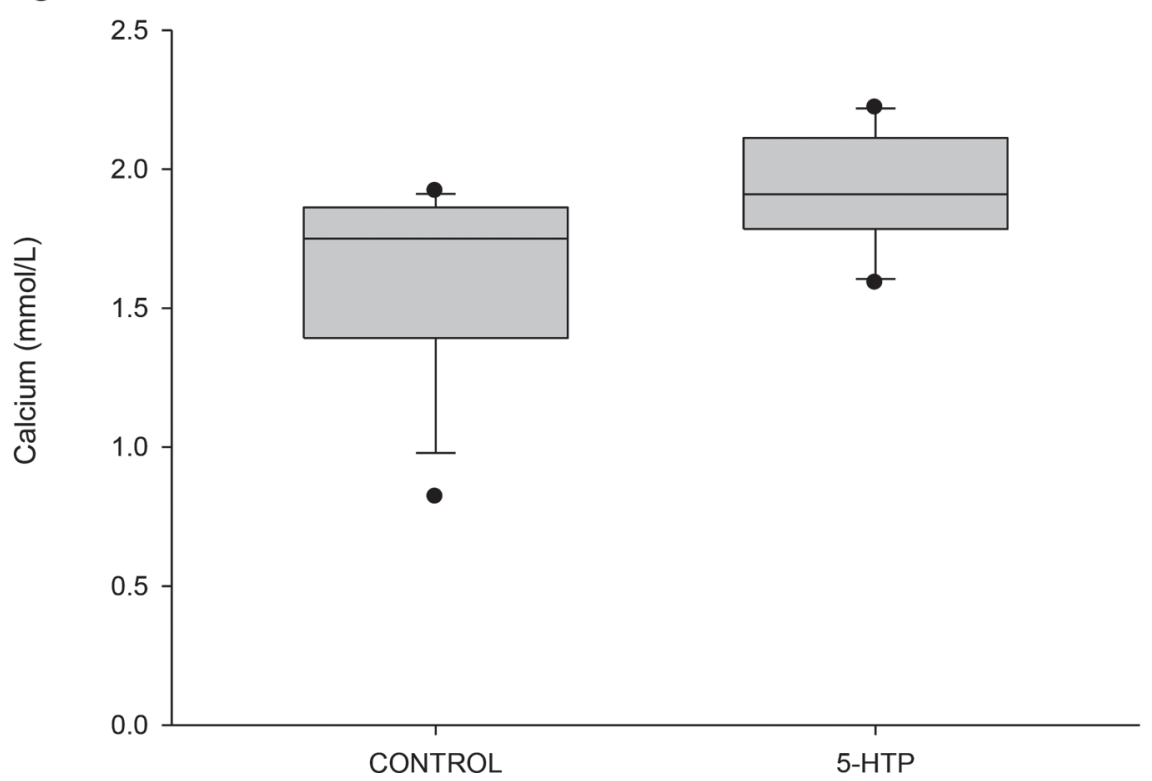

Figure 1. Serotonin (A) and calcium (B) concentrations of cows administered prepartum saline (control; $\bullet$ ) or $1 \mathrm{mg} / \mathrm{kg}$ of BW of 5-hydroxyL-tryptophan (5-HTP; $O$ ) during the experimental period. Different lowercase letters $(\mathrm{a}, \mathrm{b})$ indicate significant $(P<0.05)$ differences between time points within control group. Different uppercase letters $(\mathrm{A}-\mathrm{C})$ indicate significant $(P<0.05)$ differences between time points within 5 -HTP group. *Indicates a significant $(P<0.05)$ difference between control and 5-HTP groups within each time point. Error bars indicate the SEM. Calcium concentration box plot (C) from cows administered precalving saline (control) or $1 \mathrm{mg} / \mathrm{kg}$ of BW of 5 -HTP on d 1 after parturition. The box extends from 25 th to 75 th percentile, with a line at the median; the whiskers extend from the 5 th to 95 th percentile. 
A

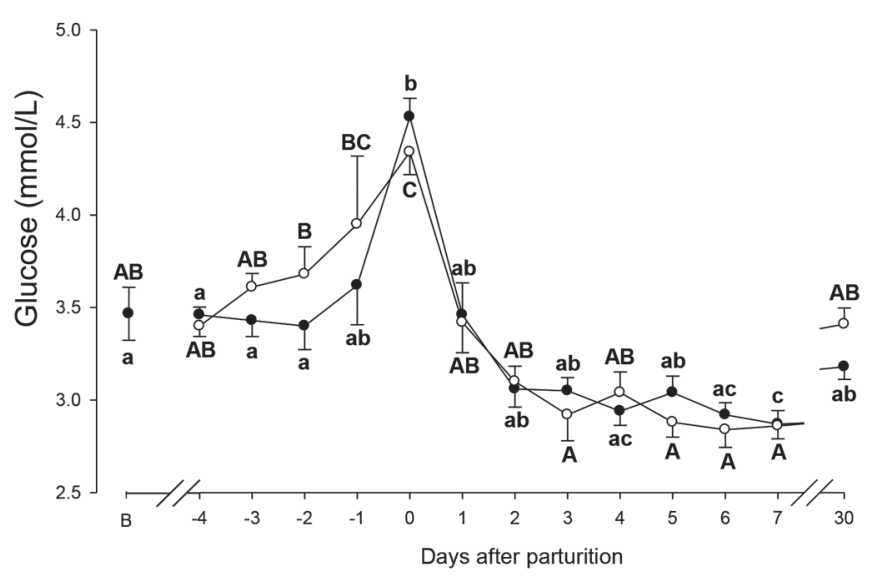

C

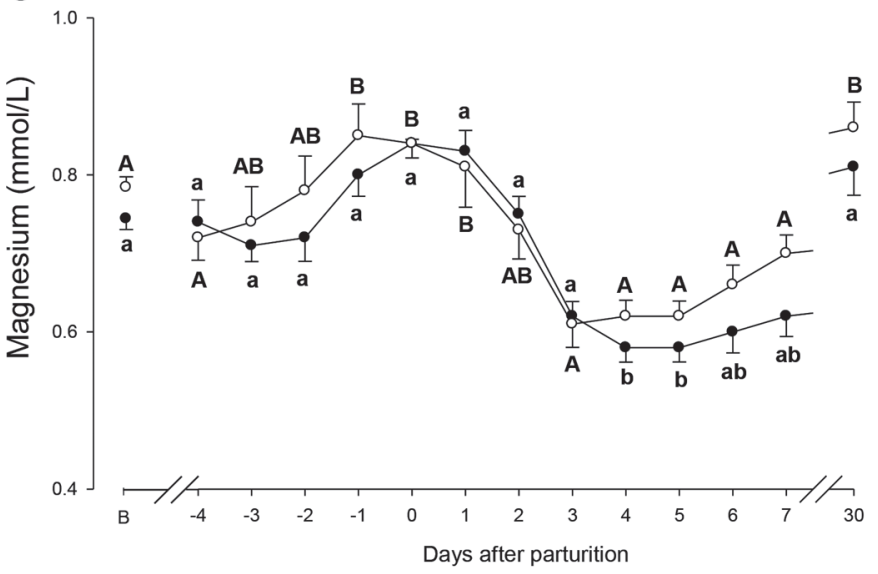

B

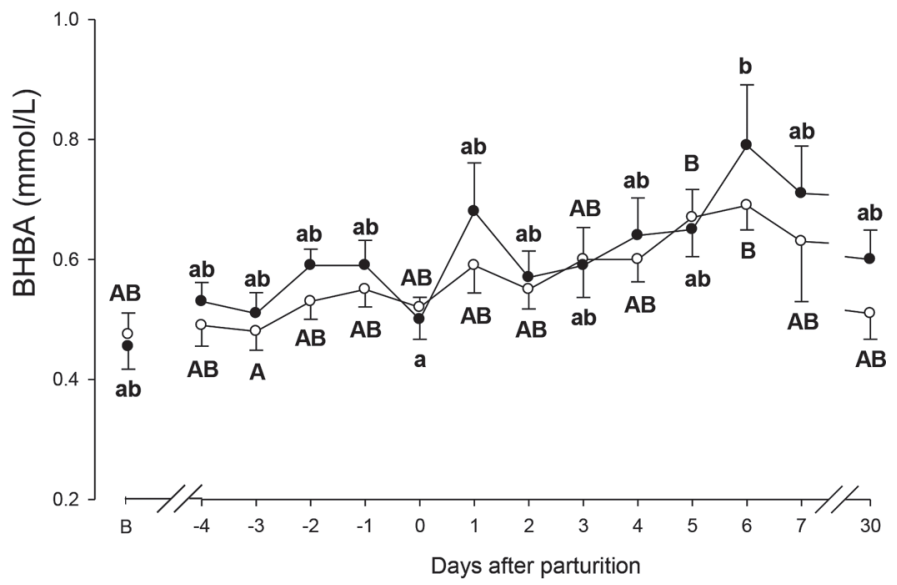

D

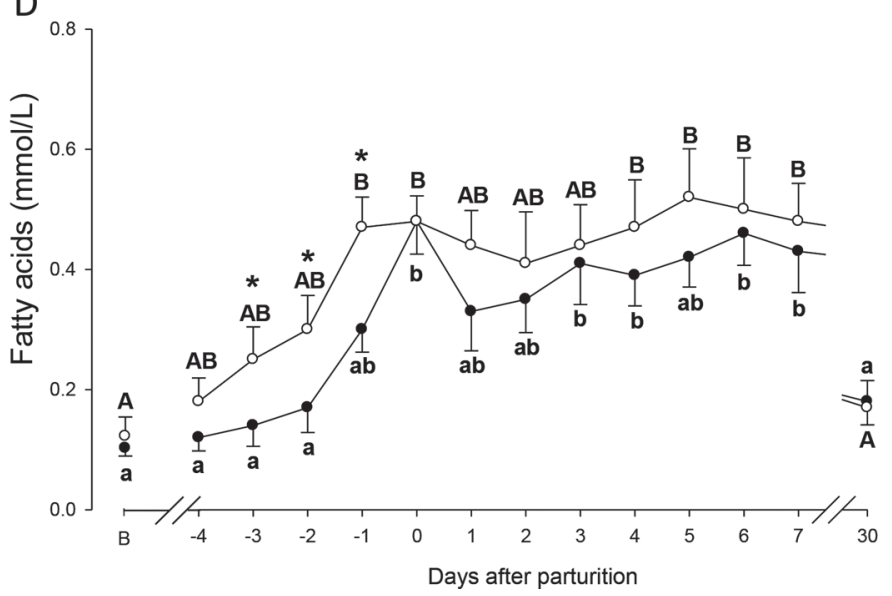

Figure 2. Glucose (A), BHB (B), magnesium (C), and fatty acid (D) concentrations of cows administered prepartum saline (control; $\bullet$ ) or 1 $\mathrm{mg} / \mathrm{kg}$ of BW of 5 -hydroxy-L-tryptophan $(5$-HTP; $O)$ during the experimental period. Different lowercase letters $(\mathrm{a}-\mathrm{c})$ indicate significant $(P<$ $0.05)$ differences between time points within control group. Different uppercase letters $(\mathrm{A}-\mathrm{C})$ indicate significant $(P<0.05)$ differences between time points within 5 -HTP group. ${ }^{*}$ Indicates a significant $(P<0.05)$ difference between control and 5 -HTP groups within each time point. Error bars indicate the SEM.

partum did not differ between groups $(68.4 \pm 16.4$ vs. $60.7 \pm 35.6 \mathrm{mg} / \mathrm{mL}$ in 5 -HTP and $\mathrm{C}$ groups, respectively; $P>0.05)$.

\section{DISCUSSION}

In recent studies it was repeatedly shown that 5 -HT plays an essential role in the regulation of calcium homeostasis. In this context, Weaver et al. (2016b) described the effect of 5 -HTP (1 mg of 5 -HTP $/ \mathrm{kg}$ of $\mathrm{BW}$ starting on $\mathrm{d}-7$ relative to parturition) on several parameters measured in blood (calcium, 5-HT, and prolactin), urine (deoxypyridinoline and creatinine), and milk (calcium). Similarly, Laporta et al. (2015) observed that similar 5-HTP dosages alter calcium and energy metabolism in late-lactation dairy cows (fatty acids, insulin, glucose, BHB, and parathyroid hormonerelated protein).
We hypothesized that the infusion of 5-HTP would modulate calcium concentrations in blood around parturition ( \pm 3 d relative to parturition). Previous studies in rodents showed that prepartum 5-HTP administration increases postpartum calcium concentrations and modulates calcium transport in the mammary gland (Laporta et al., 2014a,b). In the present study, the administration of 5 -HTP (1 mg/kg of BW) before parturition induced a remarkable increase not only in serum 5-HT concentrations, but also in the concentration of this monoamine in colostrum. The administered 5 -HTP is most efficiently used for 5-HT synthesis because 5-HTP, in contrast to the native AA tryptophan, cannot be used in any other metabolic pathway (Zafeiriou et al., 2009; Laporta et al., 2013b). Therefore, a much higher amount of tryptophan would be needed to achieve a comparable induction of 5 -HT synthesis (Richard et al., 2009). Similar results were obtained in 


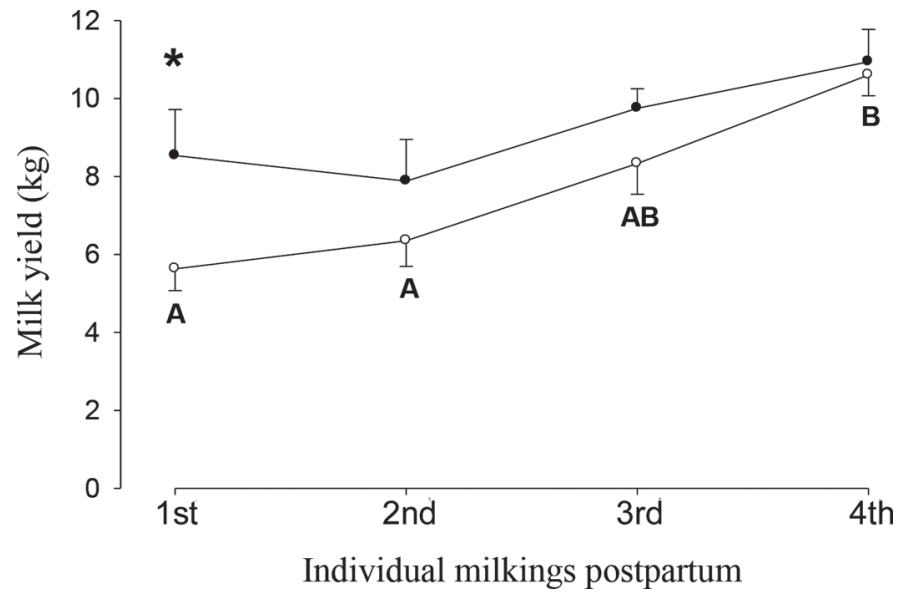

Figure 3. Milk yields from cows administered prepartum saline (control; ) or $1 \mathrm{mg} / \mathrm{kg}$ of BW of 5-hydroxy-L-tryptophan (5-HTP; O) during the first 4 milkings after parturition. Different uppercase letters (A,B) indicate significant $(P<0.05)$ differences within 5 -HTP group. *Indicates a significant $(P<0.05)$ difference between control and 5-HTP groups within each time point. Error bars indicate the SEM.

early- and late-lactation dairy cows by Weaver et al. (2016b) and Laporta et al. (2015), respectively, who observed an increase in blood 5-HT concentrations as a consequence of a daily intravenous infusion of $1 \mathrm{mg}$ of $5-\mathrm{HTP} / \mathrm{kg}$ of BW. Previous results from Hernandez et al. (2012) and Laporta et al. (2014b) indicate that 5-HT induces a pathway involving mammary-derived para-

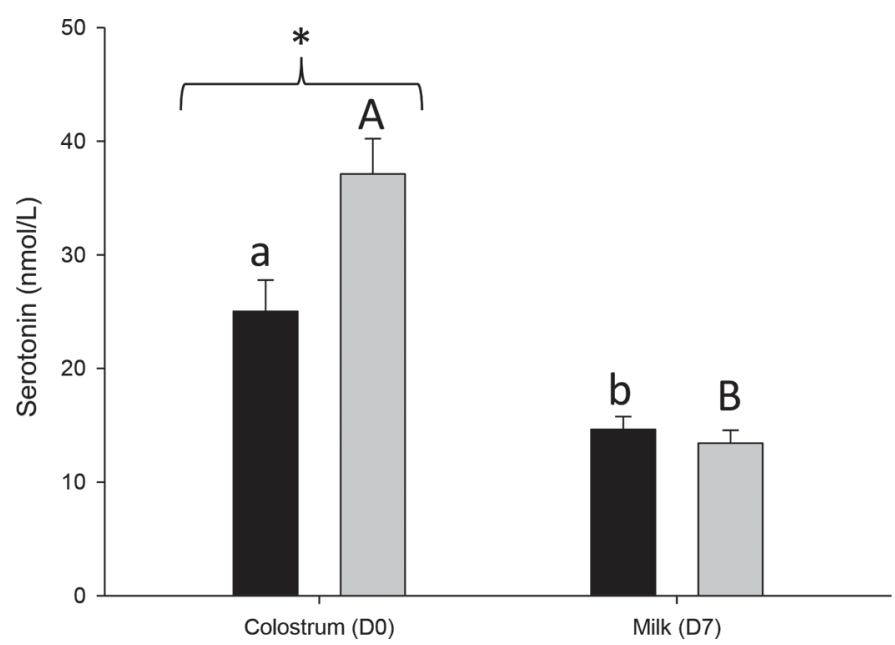

Figure 4. Colostrum (DO = parturition) and milk (D7 $=7 \mathrm{~d}$ after parturition) serotonin concentrations of cows administered prepartum saline (control; black bar) or $1 \mathrm{mg} / \mathrm{kg}$ of BW of 5-hydroxy-L-tryptophan (5-HTP; gray bar). Different lowercase letters (a,b) indicate significant $(P<0.05)$ differences between colostrum and milk within control group. Different uppercase letters $(\mathrm{A}, \mathrm{C})$ indicate significant $(P$ $<0.05$ ) differences between colostrum and milk within 5-HTP group. *Indicates a significant $(P<0.05)$ difference between control and 5-HTP groups within either colostrum or milk. Error bars indicate the SEM. thyroid hormone-related protein $(\mathbf{P T H r P})$, which acts on bone tissue to release calcium into the bloodstream (Wysolmerski, 2010; Hernandez et al., 2012; Laporta et al., 2014b). In addition, Laporta et al. (2015) found that the infusion of 5-HTP to late-lactation cows increased the urinary retention of calcium and decreased circulating PTHrP concentrations. In contrast to these findings, Syed et al. (2001) showed that the secretion of PTHrP stimulates Ca resorption in the renal tubules in humans. Therefore, it seems that the role of PTHrP in the calcium resorption by the kidney is still not clear.

According to Weaver et al. (2016b), 5-HTP infusions before parturition are affecting differently Holstein and Jersey cows, decreasing the calcium concentrations in blood from Jersey cows. Those differences may be explained by the increased excretion of calcium, with more calcium being used in muscle, intestine, or mammary gland, or even the different capacity in bone resorption between these 2 breeds. Results observed in Holstein cows by Weaver et al. (2016b) are in agreement with those shown in our study. The udder characteristics and specifically the stage of lactation seems to be another factor that affects the role of 5-HT in the calcium homeostasis, which is supported by Laporta et al. (2015), who showed that calcium concentrations in blood of cows in late lactation decreased as a consequence of 5-HTP infusion.

In the present study we did not measure any parameters related to the direct and functional link to bone metabolism, and, in agreement to the results described by Weaver et al. (2016b), it was obvious that cows receiving 5-HTP had a less dramatic decrease in calcium concentrations at the onset of lactation compared with the $\mathrm{C}$ group. Indeed, as a consequence of increased 5 -HT concentrations, cows from the 5-HTP group seemed to be able to mobilize more calcium from their bones than the $\mathrm{C}$ group cows; however, other physiological mechanisms that regulate calcium homeostasis, such as intestinal absorption or renal retention, could have also contributed to these differences. Our findings are in agreement with earlier results by Moore et al. (2015) and Laporta et al. (2013a), who found a positive correlation between serum 5-HT and calcium concentrations on d 1 of lactation, confirming a biological role of this monoamine in the regulation of calcium homeostasis. Consequently, circulating calcium in the $\mathrm{C}$ group reached concentrations below $1.8 \mathrm{mmol} / \mathrm{L}$, which is considered the limit for subclinical HC (Goff, 2008; Jawor et al., 2012; Sepúlveda-Varas et al., 2015). Conversely, animals receiving 5-HTP never reached blood calcium concentrations below $1.8 \mathrm{mmol} / \mathrm{L}$. Despite this fact, it seems that the infusion of 5 -HTP and the concomitant increase in 5-HT in blood had no effect on magnesium metabolism. Additionally, only one infusion of 5-HTP 
does not seem to be sufficient to induce an increase of 5-HT and, hence, to stabilize calcium concentrations (as indicated by the cow receiving 5-HTP only once before parturition, which is not based on statistical evidence). This single observation is in agreement with Laporta et al. (2015), who observed that at least 2 dosages of 5-HTP are necessary to increase blood 5-HT concentrations.

Concerning the relationship between 5 -HT and milk production, Matsuda et al. (2004) reported that the treatment of mouse mammary gland explants or mammospheres with 5-HT caused involution-related morphological changes. Conversely, inactivation of the 5-HT pathway by gene disruption, a tryptophan hydroxylase blocker, or a 5-HT receptor antagonist resulted in exaggeration of the developmental changes associated with milk secretion. The increased concentration of serum 5-HT in the present study through 5-HTP infusions may have inhibited lactogenesis, thus reducing colostrum yield. As a consequence, less calcium is required for colostrum synthesis. In addition, the regulation of the influx and efflux of calcium by the mammary epithelial cells may be compromised by inadequate concentrations of peripheral 5 -HT in relation to the required amount of calcium (Weaver et al., 2016a). It is possible breeding for high milk production did not change 5-HT activity, and hence the availability of calcium, whereas the calcium demand dramatically increased. Indeed, Weaver et al. (2016b) found that the infusion of 5-HTP in Holstein cows before parturition decreased the calcium content in colostrum and milk compared with the $\mathrm{C}$ group, which may contribute to an increased calcium concentration in blood. In contrast to Holstein, the same treatment increased calcium concentration in colostrum and milk in Jersey cows. In the present study, the administration of 5-HTP caused a reduced colostrum yield; however, 5-HTP did not affect IgG concentrations in colostrum compared with those from the $\mathrm{C}$ group. In contrast to the present study, neither colostrum nor milk yield was affected in the study of Weaver et al. (2016b). In our study, colostrum yield recorded in cows receiving the 5-HTP infusions was sufficient to fulfill the needs of the offspring.

Several lines of evidence have also suggested a role for 5 -HT in the regulation of energy balance, specifically in relation to fatty acid and glucose metabolism (Sugimoto et al., 1990; Watanabe et al., 2014). As described by Sumara et al. (2012), 5-HT enhances lipolysis in mice by signaling in adipocytes through the 5 -HT receptor $2 \mathrm{~B}$ receptor, which could explain the increase in fatty acids observed in the present study in cows receiving the 5-HTP treatment. An increase in fatty acid concentrations has been also described in late-lactation cows after the infusion of 5-HTP (Laporta et al., 2015). The increase in fatty acid concentrations could increase milk fat synthesis without placing the lactating animal in a severe negative energy balance. Similarly, Watanabe et al. (2014) showed increased fatty acid concentrations in sheep after the administration of 5-HT. It is plausible that the increase in concentrations of fatty acids in blood may be caused by increased adipose tissue mobilization. According to Sumara et al. (2012), 5-HT favors gluconeogenesis in mice and suppresses glucose uptake in liver by acting on the 5 - $\mathrm{HT}$ receptor $2 \mathrm{~B}$, increasing the glucose concentration in blood. Similarly, Laporta et al. (2015) observed increased glucose and decreased BHB and insulin concentrations in blood from dairy cows infused with 5-HTP during late lactation; however, this was not observed in our study. It is likely that the generally greater extent of fat mobilization in the parturient period dampened the ability of 5-HTP to increase glucose and decrease circulating BHB levels.

\section{CONCLUSIONS}

The infusion of 5-HTP (1 mg/kg of BW) for at least $4 \mathrm{~d}$ before parturition causes increased 5-HT concentrations in blood and colostrum. Furthermore, 5-HTP treatment increased total calcium concentrations around parturition compared with the control cows. We demonstrated that 5-HTP treatment was able to prevent hypocalcemia in parturient dairy cows.

\section{ACKNOWLEDGMENTS}

This study was supported by a grant of the Swiss Federal Food Safety and Veterinary Office (FSVO). The expert performance of laboratory assays by Yolande Zbinden (Veterinary Physiology, Vetsuisse Faculty University of Bern, Switzerland) is gratefully acknowledged.

\section{REFERENCES}

Agroscope. 2015. Fütterungsempfehlungen und Nährwerttabellen für Wiederkäuer (Grünes Buch). A. I. f. L. Sciences, ed, Posieux, Switzerland.

Ahern, G. P. 2011. 5-HT and the immune system. Curr. Opin. Pharmacol. 11:29-33.

Baganz, N. L., and R. D. Blakely. 2013. A dialogue between the immune system and brain, spoken in the language of serotonin. ACS Chem. Neurosci. 4:48-63.

Cameron, R. E., P. B. Dyk, T. H. Herdt, J. B. Kaneene, R. Miller, H. F. Bucholtz, J. S. Liesman, M. J. Vandehaar, and R. S. Emery. 1998. Dry cow diet, management, and energy balance as risk factors for displaced abomasum in high producing dairy herds. J. Dairy Sci. 81:132-139.

Charbonneau, E., D. Pellerin, and G. R. Oetzel. 2006. Impact of lowering dietary cation-anion difference in nonlactating dairy cows: a meta-analysis. J. Dairy Sci. 89:537-548. 
Compton, C. W., C. Heuer, K. Parker, and S. McDougall. 2007. Risk factors for peripartum mastitis in pasture-grazed dairy heifers. J. Dairy Sci. 90:4171-4180.

Gelfert, C. C., L. M. Loeffler, S. Fromer, M. Engel, K. Manner, and R. Staufenbiel. 2010. Comparison of the impact of different anionic salts on the acid-base status and calcium metabolism in non-lactating, non-pregnant dairy cows. Vet. J. 185:305-309.

Goff, J. P. 2008. The monitoring, prevention, and treatment of milk fever and subclinical hypocalcemia in dairy cows. Vet. J. 176:50-57.

Hernandez, L. L., K. A. Gregerson, and N. D. Horseman. 2012. Mammary gland serotonin regulates parathyroid hormone-related protein and other bone-related signals. Am. J. Physiol. Endocrinol. Metab. 302:E1009-E1015.

Hernandez, L. L., S. W. Limesand, J. L. Collier, N. D. Horseman, and R. J. Collier. 2009. The bovine mammary gland expresses multiple functional isoforms of serotonin receptors. J. Endocrinol. 203:123-131.

Hernandez, L. L., C. M. Stiening, J. B. Wheelock, L. H. Baumgard, A. M. Parkhurst, and R. J. Collier. 2008. Evaluation of serotonin as a feedback inhibitor of lactation in the bovine. J. Dairy Sci. 91:1834-1844.

Hernández-Castellano, L. E., A. M. Almeida, N. Castro, and A. Arguello. 2014. The colostrum proteome, ruminant nutrition and immunity: a review. Curr. Protein Pept. Sci. 15:64-74.

Jawor, P. E., J. M. Huzzey, S. J. LeBlanc, and M. A. von Keyserlingk. 2012. Associations of subclinical hypocalcemia at calving with milk yield, and feeding, drinking, and standing behaviors around parturition in Holstein cows. J. Dairy Sci. 95:1240-1248.

Kimura, K., T. A. Reinhardt, and J. P. Goff. 2006. Parturition and hypocalcemia blunts calcium signals in immune cells of dairy cattle. J. Dairy Sci. 89:2588-2595.

Laporta, J., K. P. Keil, C. M. Vezina, and L. L. Hernandez. 2014a. Peripheral serotonin regulates maternal calcium trafficking in mammary epithelial cells during lactation in mice. PLoS One 9:e110190.

Laporta, J., K. P. Keil, S. R. Weaver, C. M. Cronick, A. P. Prichard, T. D. Crenshaw, G. W. Heyne, C. M. Vezina, R. J. Lipinski, and L. L. Hernandez. 2014b. Serotonin regulates calcium homeostasis in lactation by epigenetic activation of hedgehog signaling. Mol. Endocrinol. 28:1866-1874.

Laporta, J., S. A. Moore, M. W. Peters, T. L. Peters, and L. L. Hernandez. 2013a. Short communication: Circulating serotonin (5HT) concentrations on day 1 of lactation as a potential predictor of transition-related disorders. J. Dairy Sci. 96:5146-5150.

Laporta, J., S. A. Moore, S. R. Weaver, C. M. Cronick, M. Olsen, A. P. Prichard, B. P. Schnell, T. D. Crenshaw, F. Penagaricano, R. M. Bruckmaier, and L. L. Hernandez. 2015. Increasing serotonin concentrations alter calcium and energy metabolism in dairy cows. J. Endocrinol. 226:43-55.

Laporta, J., T. L. Peters, K. E. Merriman, C. M. Vezina, and L. L. Hernandez. 2013b. Serotonin (5-HT) affects expression of liver metabolic enzymes and mammary gland glucose transporters during the transition from pregnancy to lactation. PLoS One 8:e57847.

Lehmann, M., S. K. Wall, O. Wellnitz, and R. M. Bruckmaier. 2015. Changes in milk L-lactate, lactate dehydrogenase, serum albumin, and IgG during milk ejection and their association with somatic cell count. J. Dairy Res. 82:129-134.

Lemann, J., Jr., D. A. Bushinsky, and L. L. Hamm. 2003. Bone buffering of acid and base in humans. American journal of physiology. Ren. Physiol. 285:F811-F832.

Martinez, N., C. A. Risco, F. S. Lima, R. S. Bisinotto, L. F. Greco, E. S. Ribeiro, F. Maunsell, K. Galvao, and J. E. Santos. 2012. Evalu- ation of peripartal calcium status, energetic profile, and neutrophil function in dairy cows at low or high risk of developing uterine disease. J. Dairy Sci. 95:7158-7172.

Matsuda, M., T. Imaoka, A. J. Vomachka, G. A. Gudelsky, Z. Hou, M. Mistry, J. P. Bailey, K. M. Nieport, D. J. Walther, M. Bader, and N. D. Horseman. 2004. Serotonin regulates mammary gland development via an autocrine-paracrine loop. Dev. Cell 6:193-203.

Moore, S. A., J. Laporta, T. D. Crenshaw, and L. L. Hernandez. 2015. Patterns of circulating serotonin and related metabolites in multiparous dairy cows in the peripartum period. J. Dairy Sci. 98:3754-3765.

Moore, S. J., M. J. VandeHaar, B. K. Sharma, T. E. Pilbeam, D. K. Beede, H. F. Bucholtz, J. S. Liesman, R. L. Horst, and J. P. Goff. 2000. Effects of altering dietary cation-anion difference on calcium and energy metabolism in peripartum cows. J. Dairy Sci. 83:2095-2104.

Oetzel, G. R. 1988. Parturient paresis and hypocalcemia in ruminant livestock. Vet. Clin. N. Am. Food. Pract. 4:351-364.

Reinhardt, T. A., J. D. Lippolis, B. J. McCluskey, J. P. Goff, and R. L. Horst. 2011. Prevalence of subclinical hypocalcemia in dairy herds. Vet. J. 188:122-124.

Richard, D. M., M. A. Dawes, C. W. Mathias, A. Acheson, N. HillKapturczak, and D. M. Dougherty. 2009. L-Tryptophan: Basic metabolic functions, behavioral research and therapeutic indications. Int. J. Tryptophan Res. 2:45-60.

Sepúlveda-Varas, P., D. M. Weary, M. Noro, and M. A. von Keyserlingk. 2015. Transition diseases in grazing dairy cows are related to serum cholesterol and other analytes. PLoS One 10:e0122317.

Sugimoto, Y., I. Kimura, J. Yamada, Y. Watanabe, N. Takeuchi, and K. Horisaka. 1990. Effects of serotonin on blood glucose and insulin levels of glucose- and streptozotocin-treated mice. Jpn. J. Pharmacol. 54:93-96.

Sumara, G., O. Sumara, J. K. Kim, and G. Karsenty. 2012. Gutderived serotonin is a multifunctional determinant to fasting adaptation. Cell Metab. 16:588-600.

Syed, M. A., M. J. Horwitz, M. B. Tedesco, A. Garcia-Ocana, S. R. Wisniewski, and A. F. Stewart. 2001. Parathyroid hormone-related protein-(1-36) stimulates renal tubular calcium reabsorption in normal human volunteers: Implications for the pathogenesis of humoral hypercalcemia of malignancy. J. Clin. Endocrinol. Metab. $86: 1525-1531$.

Watanabe, H., R. Saito, T. Nakano, H. Takahashi, Y. Takahashi, K. Sumiyoshi, K. Sato, X. Chen, N. Okada, S. Iwasaki, D. W. Harjanti, N. Sekiguchi, H. Sano, H. Kitazawa, M. T. Rose, S. Ohwada, K. Watanabe, and H. Aso. 2014. Effect of peripheral 5-HT on glucose and lipid metabolism in wether sheep. PLoS One 9:e88058.

Weaver, S. R., J. Laporta, S. A. Moore, and L. L. Hernandez. 2016a. Serotonin and calcium homeostasis during the transition period. Domest. Anim. Endocrinol. 56(Suppl):S147-S154.

Weaver, S. R., A. P. Prichard, E. L. Endres, S. A. Newhouse, T. L. Peters, P. M. Crump, M. S. Akins, T. D. Crenshaw, R. M. Bruckmaier, and L. L. Hernandez. 2016b. Elevation of circulating serotonin improves calcium dynamics in the peripartum dairy cow. J. Endocrinol. 230:105-123.

Wysolmerski, J. J. 2010. Interactions between breast, bone, and brain regulate mineral and skeletal metabolism during lactation. Ann. N. Y. Acad. Sci. 1192:161-169.

Zafeiriou, D. I., A. Ververi, and E. Vargiami. 2009. The serotonergic system: Its role in pathogenesis and early developmental treatment of autism. Curr. Neuropharmacol. 7:150-157. 